Belkin M.L.•

DOI: 10.25108/2304-1730-1749.iolr.2017.51.6-35

\title{
Realization of the principle of the unity of the application of law in regional declarations on human rights
}

\begin{abstract}
Despite some, sometimes very significant differences in the legal systems of the states of the world, this article proceeds from the premise that, nevertheless, in the application of law in the world there is some fundamental unity that derives from the fundamental function of law - the protection of human rights. This is confirmed by the recognition of the Universal Declaration of Human Rights (UN, 1948) by the overwhelming majority of the countries of the world, secondly by the adoption of regional Conventions (Charters) containing similar guarantees, thirdly by the declaration of similar rights in many constitutions of countries Peace. The author makes an attempt to generalize these approaches and to prove on this basis the priority of the principle of unity of the application of law before the protrusion of differences.
\end{abstract}

Keywords: unity of the application of law; human rights; Universal Declaration of Human Rights; Convention for the Protection of Human Rights and Fundamental Freedoms; African Charter on Human and Peoples Rights; American Convention on Human Rights; Cairo Declaration on Human Rights in Islam; Vienna Declaration and Programme of Action 1993.

The relevance of the development of this topic is that many authors, including Western ones, insist on an impassable civilization gap between Western and nonWestern public, in particular, legal values. For example, S. Huntington [1] calls

\footnotetext{
- Belkin Mark Leonidovich - candidate of law, lawyer, director of the law firm Mark Belkin's "Etalon" (Kiev, Ukraine). E-mail: belkinmark@list.ru
} 
this a clash of civilizations and, in particular, indicates that "the West is and will remain for years to come the most powerful civilization. Yet its power relative to that of other civilizations is declining. As the West attempts to assert its values and to protect its interests, non-Western societies confront a choice. Some attempt to emulate the West and to join or to 'band-wagon' with the West. Other Confucian and Islamic societies attempt to expand their own economic and military power to resist and to 'balance' against the West. A central axis of post-Cold War world politics is thus the interaction of Western power and culture with the power and culture of non-Western civilizations".

A similar point of view, although perhaps in a softer form, is given by A. Smolin in the publication [2]. The unsuccessful introduction of the Western model of development in the developing countries and the countries of the third world, he notes, seems to be due to the fact that the basis for development is the experience gained in a different cultural context and proposed without prior comprehension and processing in the latter's conditions. The Muslim countries, the author points out [2], criticize the UN documents in the field of human rights for the inability to take into account the cultural and religious specifics of non-Western countries. For example, in 1981, Iran's representative to the UN, Said RajaiKharasani, formulated his country's position on the Universal Declaration of Human Rights, which became the basis for most other Islamic states. He called the document "a secular understanding of the Judeo-Christian tradition", which cannot be realized by Muslims without violating Islamic legislation [2].

However, these discrepancies cannot be made it absolute, since there is a set of legal values that cannot but be recognized throughout the world. For example, as mentioned below, the same Iran voted 'for' the adoption of the Universal Declaration of Human Rights (UN, 1948), while the Byelorussian SSR, Poland, the USSR, the Ukrainian SSR, Czechoslovakia, Yugoslavia, the Union of South Africa, as well as Saudi Arabia 'abstained' [3]. As A. Smolin points out [2], the 
majority of experts, both Western and non-Western, agree that in the context of globalization and internationalization, the rational attitude to traditions that continue to play an important role in the life of each people is becoming more actual. Evolutionary development of traditions and law, in the end, maximally bring together the Western and Eastern legal postulates.

Some questions of the implementation of the principle of the unity of the application of law in regional declarations on human rights were considered by the author in his work [4].

For example, right now, the fundamental right recognized in the world is the right to life. It is unlikely that there will be people in their right mind and sober memory who will deny the universal significance of the principle of guaranteeing a person's life. In particular, the guarantees of the right to life are to some extent present in the constitutions of almost all states.

So, according to Article 3 of the Constitution of Ukraine, an individual, his life and health, honour and dignity, inviolability and security shall be recognised in Ukraine as the highest social value. According to Article 27 of the Constitution of Ukraine, every person shall have the inalienable right to life. No one shall be arbitrarily deprived of life. Protection of human life shall be the duty of the State [5].

According to Article 27 of the Constitution of Azerbaijan, everyone has the right for life [6]. According to Article 20 of the Constitution of the Russian Federation, everyone shall have the right to life [7]. According to Article 19 of the Constitution of the Republic of Haiti (1987), the State has the absolute obligation to guarantee the right to life, health, and respect of the human person for all citizens without distinction, in conformity with the Universal Declaration of the Rights of Man [8]. According to Article 21 of the Constitution of India, no person shall be deprived of his life or personal liberty except according to procedure established by law [9]. According to Article 22 of the Constitution of 
Turkmenistan (2008), each individual has the right to life and liberty and the exercise (of this right). No one can be deprived of the right to life [10]. According to Article 39 of the Constitution of Algeria, the private life and the honour of the citizen are inviolable and protected by the law [11]. According to Article 12 of the Iraqi Constitution, everyone has the right to life, liberty, and the security of his person. No one may be deprived of his life or liberty, except in accordance with legal procedures. All are equal before the courts [12]. And so on.

In Article 2 in the Cairo Declaration on Human Rights in Islam [13] also contains guarantees for the right to life: "Life is a God-given gift and the right to life is guaranteed to every human being. It is the duty of individuals, societies and states to protect this right from any violation, and it is prohibited to take away life except for a Shariah-prescribed reason. Safety from bodily harm is a guaranteed right. It is the duty of the state to safeguard it, and it is prohibited to breach it without a Shari'ah-prescribed reason".

Similarly, guarantees for other human rights are to some extent guaranteed. As pointed out in the article [14], the modern stage of interpreting human values and regulating them in constitutions is characterized, in particular, by increased attention to the provision, guarantees and protection of 'natural', 'inalienable' human rights [14, p. 68-70].

In the monograph [15], where the influence of religion on the legal regulation of different countries is investigated, the authors came to the conclusion that world religions contain a substantial number of principal differences. One of them, in particular, can be highlighted in recognition of the moral dominant of the existence of the highest 'supermaterial' essence - God (Christianity, Islam) or personal value of a person's spiritual life (Buddhism). However, the numerous differences in the dogmatic content of the essence of the faith and the theological teachings of the various world religions are not able to hide their main global-civilizational traitthey are combined in several ways in different ways and allegorically, according to 
the identity of the cultural traditions of the basic ethnic groups of the corresponding religious cultivation. They are the focus and conductors of the basic moral- Ethical standards and spiritual values of mankind. It is the integrated and relatively uniform preaching of these primordially natural human beings and enduring value dogmas that initially contributed to the global worldwide unification of human morals, morality, culture, and legal regulation [15, p. 384]. In particular, in Article 1 of the Cairo Declaration on Human Rights in Islam [13] indicates, that "all human beings form one family whose members are united by submission to God and descent from Adam". The monograph [15] also notes that in the overwhelming majority of Muslim countries, the principles of the 'western' criminal law that is considered the world's standard in all the world have replaced the Shariah criminal law, and not because the Euro-American secular law in form or content is more perfect than the Muslim Religious, and in view of the fact that the former, in a better degree than the latter, adapted the generally recognized religious values to the conditions, the state of life and the development of modern human society [15, p. 312].

It should be noted that most importantly these principles are embodied in international conventions and human rights treaties.

Thus, the Universal Declaration of Human Rights, adopted by the UN General Assembly on 10/12/1948, proclaims such fundamental human rights as the right to life, liberty and security of person; prohibition of slavery, torture or cruel, inhuman or degrading treatment or punishment; prohibition of any discrimination; the right to a fair trial; presumption of innocence; the right to freedom of thought, conscience and religion; the right to freedom of opinion and expression; the right to freedom of peaceful assembly and association; the right to own property; the right to protection of intellectual property, etc. At the adoption of the Declaration for it voted [3]: Australia, Australia, Argentina, Afghanistan, Belgium, Burma, Bolivia, Brazil, Chile, Denmark, Dominican Republic, Ecuador, Egypt, Guatemala, 
India, Greece, Guatemala, India, Iraq, Iran, Iceland, Canada, China, Colombia, Costa Rica, Cuba, Liberia, Lebanon, Luxembourg, Mexico, Netherlands, Nicaragua, New Zealand, Norway, Pakistan, Panama, Paraguay, Peru, El Salvador, Siam, Syria, United Kingdom, United States of America, Turkey, Uruguay, The Philippines, France, Chile, Sweden, Ecuador, Ethiopia - that is, the countries of all continents and the most diverse cultural traditions.

The Vienna Declaration and Program of Action adopted by the World Conference on Human Rights (Vienna, 25.06.1993) state that the conference reaffirms the solemn commitment of all States to fulfill their obligations to promote universal respect for, and observance and protection of, all human rights and fundamental freedoms for all in accordance with the Charter of the United Nations, other instruments relating to human rights, and international law; the universal nature of these rights and freedoms is beyond question (Art. 1); all human rights are universal, indivisible and interdependent and interrelated... while the significance of national and regional particularities and various historical, cultural and religious backgrounds must be borne in mind, it is the duty of States, regardless of their political, economic and cultural systems, to promote and protect all human rights and fundamental freedoms (Art. 5); Democracy, development and respect for human rights and fundamental freedoms are interdependent and mutually reinforcing (Art. 8) [16].

It is important to emphasize the provisions of the document that national, regional, historical, cultural, other specificity cannot influence the duty of states to promote and protect all human rights and fundamental freedoms.

On the basis of the Declaration of 1948, human rights declarations were adopted in many regions. The European one is the European Convention on Human Rights and Fundamental Freedoms (ECHR). As stated in the preamble to the ECHR, it is adopted, considering the Universal Declaration of Human Rights proclaimed by the General Assembly of the United Nations on 10.12.1948; 
considering that this Declaration aims at securing the universal and effective recognition and observance of the Rights therein declared. The ECHR declares guarantees of such rights as right to life; prohibition of torture or to inhuman or degrading treatment or punishment; prohibition of slavery and forced labour; right to liberty and security; right to a fair trial; freedom of thought, conscience and religion; freedom of expression; freedom of assembly and association; prohibition of discrimination. Thus, it provides for the guarantee of rights that are in full compliance with the Declaration of 1948. At the same time, the ECHR provides an effective mechanism for the protection of these rights vis-à-vis individual citizens - the European Court of Human Rights (ECHR). Later, the right to free property ownership was adopted (Protocol no. 1 of 20.03.1952).

Similar provisions are enshrined in the American Convention on Human Rights (San José, Costa Rica, 22.11.1969) [17]. At the same time, the preamble emphasizes the universal nature of human rights: the essential rights of man are not derived from one's being a national of a certain state, but are based upon attributes of the human personality, and that they therefore justify international protection in the form of a convention reinforcing or complementing the protection provided by the domestic law of the American states.

It should be noted that the American Convention on Human Rights is expected to comply with European legal traditions, since the European legal system corresponds to the legal systems of American states: the US legal system corresponds to the legal system of the Anglo-American type [18, p. 226], the legal systems of Latin American countries are close to the Romance group of European continental law, with the strong influence of American law [18, p. 291]. Thus, the States parties to the American Convention on Human Rights fully comply with European legal traditions and naturally adopted an interstate act of a European type. 
So, according to Article 4 of the American Convention on Human Rights, every person has the right to have his life respected. No one shall be arbitrarily deprived of his life. In countries that have not abolished the death penalty, it may be imposed only for the most serious crimes and pursuant to a final judgment rendered by a competent court and in accordance with a law establishing such punishment, enacted prior to the commission of the crime. The death penalty shall not be re-established in states that have abolished it. In no case shall capital punishment be inflicted for political offenses or related common crimes. Capital punishment shall not be imposed upon persons who, at the time the crime was committed, were under 18 years; nor shall it be applied to pregnant women. Every person condemned to death shall have the right to apply for amnesty, pardon, or commutation of sentence, which may be granted in all cases. Capital punishment shall not be imposed while such a petition is pending decision by the competent authority.

It should be noted that the above provision of the Convention is very wary of the death penalty, emphasizing that it cannot be restored in any case, where it is abolished. By the way, we note that under the ECHR, the death penalty has been completely and irrevocably abolished in the member countries of the Council of Europe.

According to Article 5 of the American Convention, every person has the right to have his physical, mental, and moral integrity respected. No one shall be subjected to torture or to cruel, inhuman, or degrading punishment or treatment. All persons deprived of their liberty shall be treated with respect for the inherent dignity of the human person. Punishments consisting of deprivation of liberty shall have as an essential aim the reform and social re-adaptation of the prisoners.

According to Article 6 of the American Convention, no one shall be subject to slavery or to involuntary servitude, which are prohibited in all their forms, as are the slave trade and traffic in women. No one shall be required to perform forced or 
compulsory labour. For the purposes of this article, the following do not constitute forced or compulsory labour: a) work or service normally required of a person imprisoned in execution of a sentence or formal decision passed by the competent judicial authority. Such work or service shall be carried out under the supervision and control of public authorities, and any persons performing such work or service shall not be placed at the disposal of any private party, company, or juridical person; b) military service and, in countries in which conscientious objectors are recognized, national service that the law may provide for in lieu of military service; c) service exacted in time of danger or calamity that threatens the existence or the well-being of the community; or d) work or service that forms part of normal civic obligations.

According to Article 7 of the American Convention, every person has the right to personal liberty and security. No one shall be deprived of his physical liberty except for the reasons and under the conditions established beforehand by the constitution of the State Party concerned or by a law established pursuant thereto. No one shall be subject to arbitrary arrest or imprisonment. Anyone who is detained shall be informed of the reasons for his detention and shall be promptly notified of the charge or charges against him. Any person detained shall be brought promptly before a judge or other officer authorized by law to exercise judicial power and shall be entitled to trial within a reasonable time or to be released without prejudice to the continuation of the proceedings. His release may be subject to guarantees to assure his appearance for trial. Anyone who is deprived of his liberty shall be entitled to recourse to a competent court, in order that the court may decide without delay on the lawfulness of his arrest or detention and order his release if the arrest or detention is unlawful. In States Parties whose laws provide that anyone who believes himself to be threatened with deprivation of his liberty is entitled to recourse to a competent court in order that it may decide on the 
lawfulness of such threat, this remedy may not be restricted or abolished. The interested party or another person in his behalf is entitled to seek these remedies.

According to Article 8 of the American Convention, every person has the right to a hearing, with due guarantees and within a reasonable time, by a competent, independent, and impartial tribunal, previously established by law, in the substantiation of any accusation of a criminal nature made against him or for the determination of his rights and obligations of a civil, labour, fiscal, or any other nature. Every person accused of a criminal offense has the right to be presumed innocent so long as his guilt has not been proven according to law.

It is also guaranteed: Freedom of Conscience and Religion (Art. 12), Freedom of Thought and Expression (Art. 13), Right of Assembly (Art. 15), Freedom of Association (Art. 16), Right to Property (Art. 21), Right to Judicial Protection (Art. 25) and others. Based on the American Convention, the Inter-American Court of Human Rights is being established. However, unlike the ECHR, the InterAmerican Court accepts only cases from Member States and / or the InterAmerican Commission on Human Rights (Art. 61).

The African Charter of Human and Peoples Rights, which was adopted at the meeting of the Heads of State of the Organization of African Unity on 26.06.1981 in Nairobi, deserves special attention; Entered into force on 21.10.1986 [19]. The interest in this document in the context of our study is that, firstly, the Charter was adopted by countries with clearly different cultural traditions than Europe, and secondly, most of the countries participating in this Charter did not participate in the vote on the UN Declaration of 1948 Because they did not have state independence at that time. Nevertheless, the preamble of the Charter states that it was adopted in accordance with the Charter of the United Nations and the Universal Declaration of Human Rights. At the same time, the rights (but not exclusively) are guaranteed, in particular:

- human beings are inviolable. Every human being shall be entitled to respect 
for his life and the integrity of his person. No one may be arbitrarily deprived of this right;

- all forms of exploitation and degradation of man particularly slavery, slave trade, torture, cruel, inhuman or degrading punishment and treatment shall be prohibited;

- every individual shall have the right to liberty and to the security of his person. No one may be deprived of his freedom except for reasons and conditions previously laid down by law. In particular, no one may be arbitrarily arrested or detained;

- freedom of conscience is guaranteed, the right to express and disseminate one's opinion, to receive information, freedom of association, assembly, the right to property;

- every individual shall have the right to have his cause heard. This comprises: a) the right to an appeal to competent national organs against acts of violating his fundamental rights as recognized and guaranteed by conventions, laws, regulations and customs in force; $b$ ) the right to be presumed innocent until proved guilty by a competent court or tribunal; c) the right to defence, including the right to be defended by counsel of his choice; d) the right to be tried within a reasonable time by an impartial court or tribunal.

The Charter establishes the African Commission on Human and Peoples Rights for the development and protection of these rights in Africa (Art. 30). At the same time, the Commission at the moment is not a full analogue of the ECHR, since it considers disputes only between the member states of the Charter (Art. 47).

In the context of the potential differences noted above between the European and Eastern legal systems, we will consider the Cairo Declaration on Human Rights in Islam [13]. Its main principles from the point of view of guaranteeing rights are: 
- every human being is entitled to inviolability and the protection of his good name and honour during his life and after his death (Art. 4);

- woman is equal to man in human dignity, and has rights to enjoy as well as duties to perform (Art. 6);

- human beings are born free, and no one has the right to enslave, humiliate, oppress or exploit them (Art. 11);

- everyone shall have the right to own property acquired in a legitimate way, and shall be entitled to the rights of ownership, without prejudice to oneself, others or to society in general (Art. 15);

- everyone shall have the right to enjoy the fruits of his scientific, literary, artistic or technical production and the right to protect the moral and material interests stemming there from (Art. 16);

- it is not permitted without legitimate reason to arrest an individual, or restrict his freedom, to exile or to punish him (Art. 20);

- everyone shall have the right to express his opinion freely (Art. 22).

Thus, the Cairo Declaration provides for a set of rights that are in full conformity with the UN Declaration of 1948.

Of course, the norm of article of the Cairo Declaration "all the rights and freedoms set forth in this Declaration are governed by the Islamic Sharia" is unusual for countries with Anglo-Saxon or Romano-German legal systems. However, it should be borne in mind that the States parties to the Cairo Declaration (ratified by Jordan, Bahrain, Libya, Algeria, the United Arab Emirates, Palestine, Yemen, Iraq, Kuwait, Lebanon, Qatar, Saudi Arabia, Syria, signed, but not ratified - Sudan, Morocco , Egypt, Tunisia [2]) refer to another legal system - Islamic (Islamic) law. This family of legal systems combines the right, historically consecrated by religion and custom, with modern law [18, p. 299]. Thus, the reference to the Sharia is essentially a reference to the source of Islamic (Islamic) law. However, in most cases in modern legal systems Islamic legal doctrine does 
not matter the independent source (form) of law [18, p. 334]. In the post-Soviet countries with the Muslim population, Islamic law does not fundamentally influence the state-legal life, but it can regulate its separate sides [18, p. 331].

In general, all the foregoing means the convergence of the various legal systems towards unification and the achievement of the unity of the application of law.

\section{References}

1. Huntington S. The Clash of Civilizations. Available at: http://www. stetson.edu/artsci/political-science/media/clash.pdf

2. Smolin A. Vse ob Aziatskom sude po pravam cheloveka [Everything on Asian Court on Human Rights]. Available at: http://rapsinews.ru/international publication/20150311/273311056.html

3. Johnson G. Razrabotka Vseobschey deklaratsii prav cheloveka (1946-1948) [Development of Universal Declaration on Human Rights]. Razvitie lichnosti [Development of a personality]. 2016, no. 3. Available at: http://rl-online.ru/ articles/4-03/224.html

4. Belkin M.L. Regionalnyie deklaratsii o pravakh cheloveka kak voploschenie edinstva pravoprimeneniya $\mathrm{v}$ mire [Regional Declaration on Human Rights as embodiment of unity of law enforcing in the world]. Trudyi III mezhdunar. nauchno-praktich. konf. pod red. G.B. Gridnevoy, A.B. Didikina. [Works of 3-rd Sci. Pr. Conf., ed. by G.B. Gridnevoy, A.B. Didikin]. Novosibirsk, 2014, pp. 12-17.

5. Constitution of Ukraine. Available at: http://www.unece.org/fileadmin /DAM/hlm/prgm/cph/experts/ukraine/ukr.constitution.e.pdf

6. Constitution of Azerbaijan. Available at: http://www.azerbaijan.az/portal/ General/Constitution/doc/constitution_e.pdf

7. Constitution of the Russian Federation. Available at: http://www. dadychery.org/2012/03/12/constitution-of-the-republic-of-haiti-1987/ 
9. Constitution of India. Available at: http://www.constitution.org/cons/ india/p03021.html

10. Constitution of Turkmenistan (2008). Available at: http://neutral.gov.tm/ static/documents/constitution-of-turkmenistan-final-editedpdf.pdf

11. Constitution of Algeria. Available at: http://confinder.richmond.edu/ admin/docs/local_algeria.pdf

12. The Iraqi Constitution. Available at: http://www.uznal.org/constitution. php?text=Iraq\&language $=\mathrm{e}$

13. Cairo Declaration on Human Rights in Islam (Cairo, 05.08.1990). Available at: http://www.bahaistudies.net/neurelitism/library/Cairo_Declaration _on_Human_Rights_in_Islam.pdf

14. Chirkin V.E. Obschechelovecheskie tsennosti i rossiyskoe pravo [Universal values and Russian law]. Obschestvennyie nauki i sovremennost [Social sciences and the present]. 2001, no. 2, pp. 64-76. Available at: http://ecsocman. hse.ru/data/903/814/1217/007yIRKIN.pdf

15. Zhitnigor B.S. Na rubezhe tyisyacheletiy: svoboda sovesti i pravo [At the turn of millennium: conscience freedom and law]. Benderyi , 2009, $480 \mathrm{p}$.

16. Vienna Declaration and Programme of Action (Vein, 25.06.1993) Available at: http://www.ohchr.org/EN/ProfessionalInterest/Pages/Vienna.aspx

17. American Convention on Human Rights (San José, Costa Rica, 22.11. 1969). Available at: http://www.hrcr.org/docs/American_Convention/oashr 2.html

18. Skakun O.F. Obschee sravnitelnoe pravovedenie: Akademicheskiy kurs [Common Comparative Law: Academic course]. Kiev, 2008, 464 p.

19. African Charter on Human and Peoples Rights (Nairobi, 26.06.1981). Available at: http://www.humanrights.se/wp-content/uploads/2012/01/AfricanCharter-on-Human-and-Peoples-Rights.pdf 